\title{
Effect of Corporate Sustainability on Corporate Reputation and Firm Performance of Companies in Thailand
}

\author{
Nichanal Lamsam ${ }^{1}$ \\ ${ }^{1}$ International College of National Institute of Development Administration, Bangkok, Thailand \\ Correspondence: Nichanal Lamsam, the International College of NIDA, the National Institute of Development \\ Administration (NIDA), Bangkok 10240 Thailand. Tel: 66-81-925-2559. E-mail: nichanal@gmail.com
}

Received: August 21, 2020

doi:10.5539/ass.v16n11p31
Accepted: September 3, 2020

Online Published: October 31, 2020

URL: https://doi.org/10.5539/ass.v16n11p31

\begin{abstract}
This research analyzes the contribution of corporate sustainability practice on corporate reputation and firm performance of companies in Thailand. This research is based on the Triple Bottom Line framework which conceptualizes sustainability into three dimensions: environmental, social, and economic. The data were obtained from a total of 196 firms through online questionnaires surveys. Partial least squares structural equation modeling was used for the data analysis. The results show that all three dimensions of corporate sustainability positively and significantly determine corporate reputation. Corporate reputation also positively and significantly determines firm performance. Lastly, corporate reputation is also found to mediates the linkage between all three dimensions of corporate sustainability practice and firm performance.
\end{abstract}

Keywords: sustainability, firm performance, stakeholders, strategic management

\section{Introduction}

The concept of sustainability has been gaining more and more attention from modern academics and practitioners around the globe, including governments, researchers, policy makers, companies, media, and consumers (Kumar \& Christodoulopoulou, 2014; Martínez \& del Bosque, 2014). Especially in the business sector, globalization has impelled a growing number of companies to adopt sustainability practices as a competitive advantage and as a mean for securing the future of the business (Cronin, Smith, Gleim, Ramirez, \& Martinez, 2011; Gupta \& Kumar, 2013; Martínez \& del Bosque, 2014). Whilst the orthodox paradigm of business operation would use resources purely for profitability, contemporary management has raised concerns over the balance consumption of resources (Kumar \& Christodoulopoulou, 2014). Firms that seek primarily to maximize their profits will not be able to survive in the long run, and profit and purpose that give value to the society will need to coexist for firms' continual prosperity (Govindarajan \& Srinivas, 2012). This shifted paradigm has driven expectations and transformations at the company and industry level toward sustainability initiatives.

The topic of corporate sustainability has been investigated in the research as it is believed to help in securing external support, especially from customers and relevant stakeholders (Kumar \& Christodoulopoulou, 2014). Many past studies attempted to relate the firm's sustainability to stakeholders' perceptions, such as image (Martínez \& del Bosque, 2014; Pfau, Haigh, Sims, \& Wigley, 2008), reputation (Sroufe \& Gopalakrishna-Remani, 2019), credibility (Pfau et al., 2008), and customer satisfaction (Luo \& Bhattacharya, 2006). Despite the growing prevalence of sustainability practices, there are some research gaps that need to be further explored. Past sustainability studies were conducted mostly in a limited number of developed countries (Brown, 2011; Martínez \& del Bosque, 2014); there is a limited amount of research demonstrating whether sustainability practices matter for firms in developing countries. Because firms operating in developed countries and developing countries are facing different kinds of environments and constraints, such as laws and regulations, consumer trends, and knowledge of the personnel, it is important for research to explore the role of sustainability practices, in the context of developing countries, to clarify whether the effect of sustainability practices matters for firms in this context.

Considered the gaps mentioned earlier, the objective of this research is to analyze the contribution of sustainability practices to business performance using the sample of firms in Thailand. The definition of corporate sustainability is adopted according to the Triple Bottom Line framework (Elkington, 1999) which 
conceptualizes sustainability into three dimensions: environmental, social, and economic. In particular, this research proposes that the effect of these three dimensions of sustainability practices on business performance could be mediated by corporate reputation. By using the data collected from firms in Thailand, this research will expand the knowledge on whether sustainability practices could contribute to firm performance in a developing country like Thailand.

\section{Literature Review}

\subsection{Corporate Sustainability}

When it comes to sustainability concept that is incorporated into business and organizations, it can be broadly referred to as corporate sustainability (Marrewijk \& Werre, 2003). The call for attention to the concept has emerged due to global economic circumstances and the demands from consumers that force business organizations to strive for optimal financial performance in delivering better products and services quality, while preserving the environment, enhancing society, and being compliant with applicable laws and regulations (Miles \& Covin, 2000). According to Balachandran and Chandrasekaran (2011), corporate sustainability involves firms' strategies and implementations that align with the needs of present stakeholders, while also protecting, improving, and supporting the future needs of ecological and human resources.

Modern literature often describes corporate sustainability based on the Triple Bottom Line (TBL) theory from Elkington (1999), which identifies three sustainability dimensions: (1) social, (2) environmental, and (3) economic. This TBL-based definition of sustainability has been widely recognized by many academics and practitioners because it is believed that the TBL framework represents comprehensive perspectives of corporate sustainability practices in business, and that it should be incorporated into business goals and metrics as part of a business performance assessment (Elkington, 1999; Gupta \& Kumar, 2013; Kumar \& Christodoulopoulou, 2014; Martínez \& del Bosque, 2014; Sheth, Sethia, \& Srinivas, 2011). The essence of TBL is that it takes into consideration the business economic goals such as ROI, profits, and other financial indicators (Kumar \& Christodoulopoulou, 2014; Slaper \& Hall, 2011). TBL suggests that firms should run their business in a way that protects and enhances the environment and society, while still performing well economically (Elkington, 1999; Kumar \& Christodoulopoulou, 2014; Martínez \& del Bosque, 2014; Sheth et al., 2011).

\subsection{Dimension of Corporate Sustainability}

\subsubsection{Environmental Dimension}

The environmental dimension of sustainability has been obtained the most attention among the three dimensions (Sheth et al., 2011). This dimension is concerned about what a business can do to minimize its negative impact to the environment while maintaining the natural capital (Goodland, 1995; Kumar \& Christodoulopoulou, 2014). Examples of environmental variables include water quality, air quality, pollution and toxic waste, natural resources, land use, and energy consumption (Slaper \& Hall, 2011). The main assumption of the environmental dimension is that the imbalance rate of consumption to natural resources causes environmental damages, which consequently threatens human health and well-being (Baldassarre, Calabretta, Bocken, \& Jaskiewicz, 2017). As a result, the key essence of the environmental dimension of sustainability aims to promote the balance of human activities that will not exceed nor diminish the capacity of the Earth's ecosystem (Orlitzky, Siegel, \& Waldman, 2011).

\subsubsection{Social Dimension}

The social dimension of sustainability is concerned about the nonfinancial aspects of the wealth of people, the public, communities, and society (Choi \& Ng, 2011). Social sustainability can be reflected through various indicators such as citizenship, employment compensation, health and safety quality, social capital, legislative issues, philanthropy, access to social resources, human rights, labor rights, social equity, education, and the well-being of people at the community level (Choi \& Ng, 2011; Guang \& Charoensukmongkol, 2020; Phungsoonthorn \& Charoensukmongkol, 2019; Sheth et al., 2011; Slaper \& Hall, 2011). The social dimension has also gained significant attention from the academics and practitioners in recent decades as there has been an increase in scandals regarding public distrust towards firms operations (Charoensukmongkol, 2016), as well as an increased public demand for firms to take responsibilities for social well-being (Choi \& Ng, 2011; Martínez \& del Bosque, 2014). This can be supported by the rising number of business activities that take the form of discretionary projects, which is usually referred to as corporate social responsibility (Koirala \& Charoensukmongkol, 2020; Martínez \& del Bosque, 2014).

\subsubsection{Economic Dimension}

The economic dimension of sustainability considers a firm's impact on the economic and financial performance 
of stakeholders, as well as on the economic system at local, national, and global levels (Dahlsrud, 2008). With the enduring economic crisis, this brought society's attention towards the consideration of economic sustainability (Choi \& Ng, 2011). Some researchers perceive economic dimension to be the most desirable dimension by business organizations since it helps businesses achieve financial strength and protect themselves from going bankrupt (Gupta \& Kumar, 2013). Sheth et al. (2011) identifies two aspects of economic dimension: the first aspect considers financial performance of the firm (e.g. profit, cost reduction), and the second considers the economic performance and standard of living of external stakeholders (e.g., debt burden; personal income pressure; work-life balance; job growth; and standard of living of the consumers, suppliers, and communities).

\subsection{Effect of Corporate Sustainability on Corporate Reputation and Firm Performance}

Corporate sustainability can play an important role in enhancing corporate reputation. Miles and Covin (2000) have claimed that one possible source of superior corporate reputation is when firms consistently show they act responsibly in accordance with environmental, social, and economic values. Their argument is also in line with assumptions from other scholars such as Unerman and Bennett (2004) and Gray, Kouhy, and Lavers (1995), who stated that sustainability dimensions and a firm's perception are related. In particular, the ability of a firm to demonstrate its commitment to key stakeholders' expectations is significant for its survival (Miles \& Covin, 2000), and these expectations can be achieved by understanding stakeholders from the aspects of social, environmental, and economic dimensions (Unerman \& Bennett, 2004). According to Unerman and Bennett (2004), the degree that these stakeholder expectations are satisfied can lead to an improved social perception towards the firm. Corporate reputation is also a kind of social perception that represents a collective perception towards a firm's particular attribute from the view of stakeholders, which can be both insiders and outsiders (Fombrun, 2001; Nguyen \& Leblanc, 2001). Similarly, Gray et al. (1995) also stated that when firms reveal their sustainability initiatives, this enhances their corporate image and reputation. The relationship between the TBLs of sustainability and a firm's perceptions has also been empirically supported by some scholars. For example, Martínez and del Bosque (2014) conducted a study on Spanish hotel customers and found that the environmental, social, and economic dimensions of sustainability are positively related to corporate image and corporate reputation. S. Brammer, Millington, and Rayton (2007) found that corporate sustainability practice is positively related to employees' perceptions in terms of organizational commitment. Park, Lee, and Kim (2014) demonstrated that a firm's fulfillment of the economic and legal dimensions of corporate sustainability practices has a positive impact on corporate reputation. S. J. Brammer and Pavelin (2006) found that firms' environmental performances that align with stakeholders' environmental concerns could enhance the reputation of the companies. Based on all the literature and empirical support, this study proposes that the three dimensions of corporate sustainability are positively associated to corporate reputation. This leads to the following hypotheses.

H1: Organizational practice of environmental dimension of corporate sustainability is positively associated with corporate reputation.

$\mathrm{H} 2$ : Organizational practice of social dimension of corporate sustainability is positively associated with corporate reputation.

H3: Organizational practice of economic dimension of corporate sustainability is positively associated with corporate reputation.

\subsection{Corporate Reputation as the Mediator of Corporate Sustainability Practices and Firm Performance}

In addition to the direct effect of corporate sustainability practices on corporate reputation, this research proposes that corporate reputation can mediate the association between corporate sustainability practices and firm performance. In particular, corporate reputation is regarded as an important factor in determining firm performance. From the perspective of a resource-based view (RBV) of firms, corporate reputation is considered a critical resource that competitors cannot replicate and catch up with in a short period of time (Charoensukmongkol, 2020). Firms with favorable reputations are more likely to be trusted by business partners and customers; therefore, their reputations contribute to their ability to gain a more competitive advantage and to perform better than other direct competitors in the market (Fombrun, 1996; Miles \& Covin, 2000). The relationship between corporate reputation and firm performance has also been confirmed in many studies. For financial aspect of performance, corporate reputation has been found to influence factors such as profitability (Roberts \& Dowling, 2002) and firm market value (Chauvin \& Hirschey, 1994). For non-financial aspects of performance, corporate reputation has been related to factors such as sales, market share (Shapiro, 1982), customer loyalty (Andreassen \& Lindestad, 1998; Nguyen \& Leblanc, 2001), effectiveness of new product introduction, and recovery ability after crisis (Dowling, 2001). Considered this critical role of corporate reputation, this study proposes that corporate reputation that firms generated from the three aspects of corporate 
sustainability practices can positively determine firm performance. This argument suggests that the effect of the three aspects of corporate sustainability practices on firm performance might be mediated by corporate reputation. This leads to the following hypothesis.

Hypothesis 4: Corporate reputation mediates the positive associated between environmental dimension of corporate sustainability practice and firm performance.

Hypothesis 5: Corporate reputation mediates the positive associated between social dimension of corporate sustainability practice and firm performance.

Hypothesis 6: Corporate reputation mediates the positive associated between economic dimension of corporate sustainability practice and firm performance.

\section{Methods}

\subsection{Sample Selection and Data Collection}

The sampling frame of this research is the list of companies in Thailand provided on the website of the Department of Business Development (DBD) under the Ministry of Commerce of Thailand. The planned samples of 1,000 firms from various business sectors were randomly selected from the list of firms in the sampling frame. The online self-administered questionnaire survey was used for data collection. The online questionnaire was created using the SurveyMonkey survey platform. The link to the online survey was sent to the target informants by e-mail. The emails were directed to a person in the companies who held an upper management position. This group of informants was an appropriate source of information because they tended to have a good understanding of the firm's strategic and operational activities. At the beginning of the online questionnaire survey, the objective of the research, as well as the ethical policy about confidentiality and anonymity assurance was described. Data collection started from the beginning of May until the end of June 2020. At the end of the data collection period, a total of 196 completely filled surveys were obtained; this total accounted for a 19.6 percent response rate.

\subsection{Measures}

Corporate sustainability practices were measured by the scale of Martínez and del Bosque (2014). The scale consisted of 17 items that assess corporate sustainability in the three dimensions including the economic aspect (4 items), social aspect (6 items), and environmental aspect (7 items). All items were measured on a 7-point Likert scale ranging from 1 (Strongly disagree) to 7 (Strongly agree).

Corporate reputation was measured by adapting 10 items from the "Reputation Quotient" scale developed by Charles J Fombrun, Gardberg, and Sever (2000). Three aspects of corporate reputation were selected for this study, including emotional appeal, workplace environment, and financial reputation. The items were rated on a 7-point Likert scale ranging from 1 (Strongly disagree) to 7 (Strongly agree).

Firm performance was measured using a 5-item scale developed by Yau et al. (2007), which is a self-reported measure of firm performance. The subjective evaluation of firm performance is widely accepted in research because it is easier to address a cross-industry comparison (Tarsakoo \& Charoensukmongkol, 2019; Vij \& Bedi, 2016). Moreover, prior research suggested that firm performance is sensitive information; thus, respondents were more likely to provide a subjective performance evaluation to outsiders rather than revealing financial data of their companies (Charoensukmongkol, 2015; Charoensukmongkol \& Sasatanun, 2017; Sapienza, Smith, \& Gannon, 1988). In particular, the scale by Yau et al. (2007) was chosen because it is concise and covers firm performance dimensions in terms of financial and marketing performance. The first three items of the scale reflect financial performance (including overall profit, profit margin, and return on investment) and another two items reflect marketing performance (including sales volume and market share). The respondents were asked to rate the firm performance items, in terms of the perceived performance in comparison to the firm's industry competitors, on a 7-point Likert scale ranging from 1 (Significantly worse than other competitors) to 7 (Significantly better than other competitors).

\subsection{Control Variables}

Some characteristics of firms that might influence corporate reputation and firm performance were considered as control variables in the data analysis. Control variables included firm size and CEO tenure. Firm size was measured by the value of total assets. CEO tenure was measured by the number of years the CEO has been in the position.

\subsection{Data Analysis}

The model was analyzed by using Partial Least Squares Structural Equation Modeling (PLS-SEM). PLS-SEM is 
more appropriate than covariance-based SEM because it allows smaller sample sizes and is more efficient when data are not distributed normally (Hair Jr, Hult, Ringle, \& Sarstedt, 2016). These advantages of PLS-SEM are suitable for the sample size of the data used in this research which was quite small $(\mathrm{n}=196)$. Moreover, PLS-SEM is suitable because the results of the Jarque-Bera and the Robust Jarque-Bera tests of normality indicated that all variables were not normally distributed. The PLS-SEM analysis was performed by using WarpPLS software.

\section{Results}

\subsection{Measurement Model Assessment}

The validity and reliability of the constructs were assessed. First, a convergent validity test was evaluated by factor loadings. The analysis showed that all factor loadings were above 0.5 (Hair, Ringle, \& Sarstedt, 2011); thus, the good quality of the convergent validity was confirmed. A discriminant validity test was evaluated by assessing whether the square root of the average variance extracted (AVE) of each latent variable was higher than the latent construct's correlation with other latent variables (Fornell \& Larcker, 1981). As reported in Table 1, this requirement was satisfactory. Construct reliability was assessed by Cronbach's alpha coefficient and the composite reliability coefficient; these two coefficients should be higher than 0.7 (Nunnally, 1978). As shown in Table 1, all constructs had coefficients that meet the minimum requirement.

Table 1. Correlation among Variables and Square Roots of Average Variance Extracted

\begin{tabular}{|c|c|c|c|c|c|c|c|c|c|}
\hline Variables & $\begin{array}{l}\text { Cronbach's } \\
\text { Alpha } \\
\text { Coefficient }\end{array}$ & $\begin{array}{l}\text { Composite } \\
\text { Reliability } \\
\text { Coefficient }\end{array}$ & EOCS & SOCS & ENCS & COR & FP & SIZE & CTN \\
\hline EOCS & .907 & .935 & (.89) & $.55^{* * *}$ & $.47 * *$ & $.67 * *$ & $.59 * *$ & $.27 * *$ & -.04 \\
\hline SOCS & .892 & .918 & & $(.81)$ & $.79 * *$ & $.64 * *$ & $.35^{* *}$ & $.15^{*}$ & -.02 \\
\hline ENCS & .948 & .958 & & & $(.87)$ & $.61^{* *}$ & $.39^{* *}$ & $.23^{* *}$ & .05 \\
\hline COR & .93 & .941 & & & & (.79) & $.55^{* *}$ & $.21^{* *}$ & -.1 \\
\hline FP & .935 & .951 & & & & & (.89) & $.29 * *$ & .01 \\
\hline SIZE & $\mathrm{n} / \mathrm{a}$ & $\mathrm{n} / \mathrm{a}$ & & & & & & (1) & -.09 \\
\hline $\mathrm{CTN}$ & $\mathrm{n} / \mathrm{a}$ & $\mathrm{n} / \mathrm{a}$ & & & & & & & (1) \\
\hline
\end{tabular}

Note. $* \mathrm{p}<.05, * * \mathrm{p}<.01$

The square roots of average variance extracted are shown in the parentheses.

EOCS = economic dimension of corporate sustainability, SOCS=social environmental dimension of corporate sustainability, $\mathrm{ENCS}=$ environmental dimension of corporate sustainability, $\mathrm{COR}=$ corporate reputation, $\mathrm{FP}=$ firm performance, $\mathrm{SIZE}=$ firm size, $\mathrm{CTN}=\mathrm{CEO}$ tenure.

Lastly, the test of multicollinearity was conducted by using full Variance Inflation Factor (VIF) statistics. According to Petter, Straub, and Rai (2007), full VIF indicators should be less than 3.3. The results showed that all full VIF indicators were lower than 3.3 for all variables, thereby lessening the concern about multicollinearity problem.

\subsection{Hypotheses Testing}

Results from hypotheses testing are reported in Figure 1. The standardized coefficient and t-values were calculated using a bootstrap resampling technique with 100 subsamples, as Efron, Rogosa, and Tibshirani (2004) recommended.

Hypothesis 1 proposes that the organizational practice of environmental dimension of corporate sustainability is positively associated with corporate reputation. The result confirmed they are positively and significantly related $(\beta=.247 ; \mathrm{p}=.001)$. Thus, hypothesis 1 is supported. Hypothesis 2 proposes that the organizational practice of social dimension of corporate sustainability is positively associated with corporate reputation. The result confirmed they are positively and significantly related $(\beta=.203 ; \mathrm{p}=.021)$. Thus, hypothesis 2 is supported. Hypothesis 3 proposes that the organizational practice of economic dimension of corporate sustainability is positively associated with corporate reputation. The result confirmed they are positively and significantly related $(\beta=.443 ; \mathrm{p}<.001)$. Thus, hypothesis 3 is supported. 
Hypothesis 4 proposes that corporate reputation mediates the positive association between environmental dimension of corporate sustainability practice and firm performance. Prior to the mediating effect estimation, the direct link between corporate reputation and firm performance was analyzed. The analysis showed that corporate reputation was positively and significantly associated with firm performance $(\beta=.516 ; p<.001)$. Then, the mediating effect was assessed by the method suggested by Preacher and Hayes (2004). The result confirmed the positive mediation effect of corporate reputation, which is statistically significant $(\beta=.127 ; p=.005)$. Thus, hypothesis 4 is supported. Hypothesis 5 proposes that corporate reputation mediates the positive association between the social dimension of corporate sustainability practice and firm performance. The result confirmed the positive mediation effect of corporate reputation, which is statistically significant $(\beta=.104 ; p=.012)$. Thus, hypothesis 5 is supported. Hypothesis 6 proposes that corporate reputation mediates the positive association between the economic dimension of corporate sustainability practice and firm performance. The result confirmed the positive mediation effect of corporate reputation, which is statistically significant $(\beta=.228 ; p<.001)$. Thus, hypothesis 6 is supported.

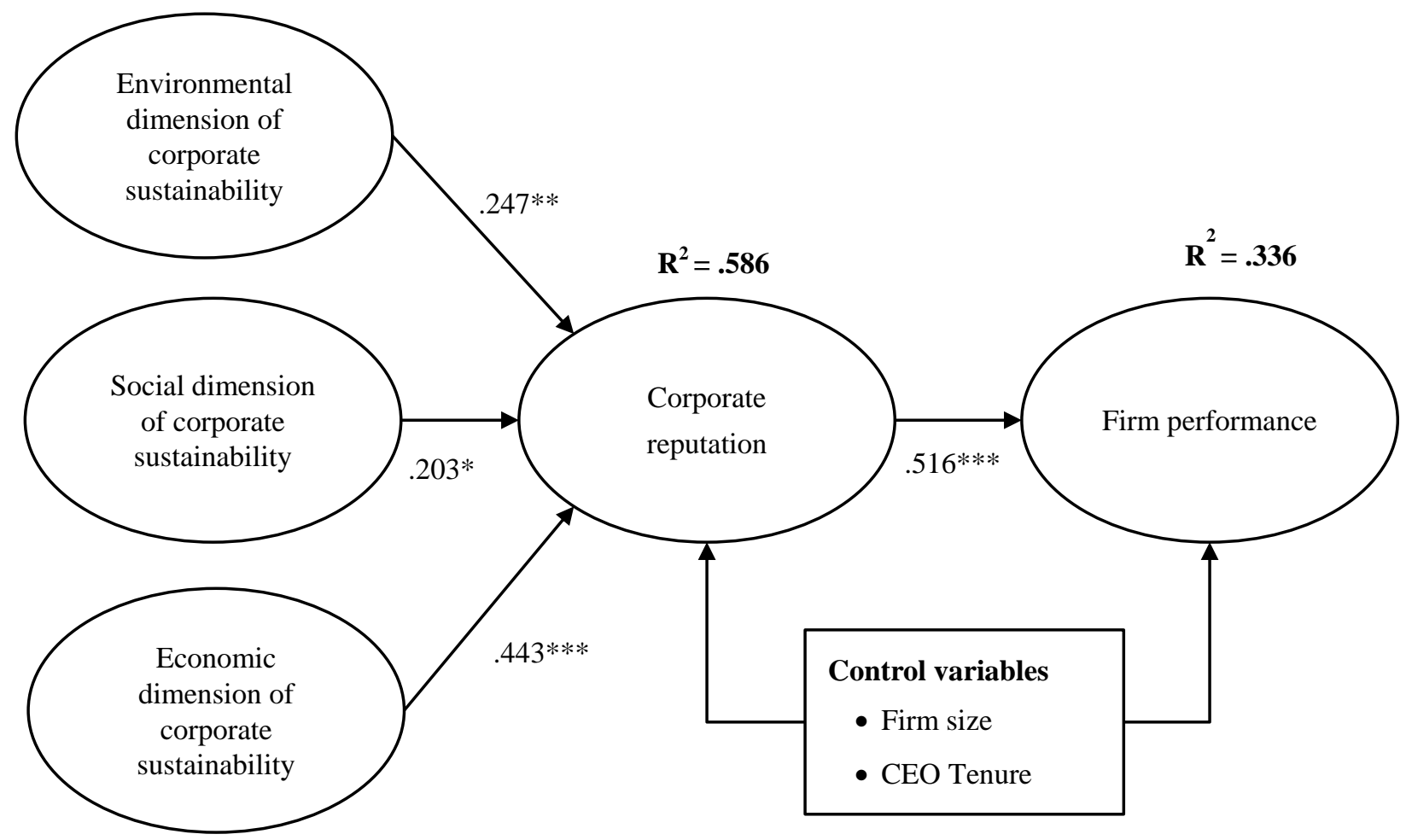

Note. $* \mathrm{p}<.05, * * \mathrm{p}<.01, * * * \mathrm{p}<.001$.

Standardized coefficients are reported.

Figure 1. Results from Hypotheses Testing

Regarding the effects of the control variables that were statistically supported, the results only showed that corporate reputation is positively and significantly related with firm size $(\beta=.184 ; \mathrm{p}<.001)$, whereas firm performance is positively and significantly related with CEO tenure $(\beta=-.086 ; p=.011)$.

\section{Discussion and Conclusion}

\subsection{Discussion of the Results}

The main objective of this research is to analyze the contribution of corporate sustainability practice on corporate reputation and firm performance by using the sample of firms in Thailand. Firstly, the results from the PLS-SEM analysis confirmed the significant effect of corporate sustainability practices on corporate reputation. The findings suggested that firms implementing environmental, social, and economic dimensions of corporate 
sustainability tended to demonstrate a higher level of corporate reputation than firms that did not. These results imply that the practice of these three dimensions of corporate sustainability may be important for firms to gain good reputations in the industry. Moreover, the analysis found that the good corporate reputation that firms exhibited played a significant role in determining the level of performance they achieved. This implies that corporate reputation might be important for firms to obtain better business performance. Lastly, the result showed that corporate reputation also mediates the linkage between all three dimensions of corporate sustainability practice and firm performance. This result implies the mechanism by which firms engaging in corporate sustainability practice gained better performance might be explained by the good corporate reputation they obtained from implementing corporate sustainability practices.

Overall, the results from this research are consistent with literature that emphasizes the benefits that firms obtain from corporate sustainability practices. The findings about the effect of corporate sustainability practices on corporate reputation is relatively consistent with prior research showing that sustainability-related practices have a positive effect on favorable perceptions of stakeholders (Martínez \& del Bosque, 2014; Park et al., 2014; Vaitoonkiat \& Charoensukmongkol, 2020a, 2020b). This is especially in line with the work of Martínez and del Bosque (2014), who found that the economic, social, and environmental dimensions of sustainability play a crucial role in predicting corporate image and corporate reputation. Moreover, the results showing that corporate sustainability practices indirectly explain firm performance through the mediating effect of corporate reputation supports prior studies regarding the role of firm reputation in helping firm gain competitive performance in the industry (Kotha, Rajgopal, \& Rindova, 2001; Lee \& Roh, 2012; Roberts \& Dowling, 2002).

\subsection{Research Contributions}

The research adds knowledge contribution to prior studies on the benefits of sustainability practices. In particular, the results from this study contribute to the limited amount of research demonstrating whether sustainability practices matter for firms in the developing countries. This research provides more evidence to support the contribution of sustainability practices of firms in Thailand, which is among the developing nations that still lack supporting evidence on this topic. In addition to the direct effect of corporate sustainability practices on firm performance that were confirmed in prior studies, the present research clarifies that the reason explaining why corporate sustainability practices contributed to firm performance could be transferred from the corporate reputation that firms achieve from implementing corporate sustainability practices.

\subsection{Managerial Implications}

There are some managerial implications that can be taken from the overall results of this research. This research suggests that top management should consider sustainability practices as part of the key strategic initiatives of their firm. Corporate practices of environmental, social, and economic sustainability not only help reduce the world's sustainability problems, but also are beneficial to the firm to promote its reputation and business performance. Some examples of activities that management can take related to environmental sustainability include recycling and integrating green practices into its supply chain. For social sustainability, management may need to initiate corporate social responsibility programs and encourage diversity in the workplace. For economic sustainability, management may need to develop a strategic plan for company growth and prosperity in the long run to promote job security for their employees, as well as to help the company to maintain financial strength and to secure their competitive position in the industry. In addition, in order for management to optimize the benefits that firms can gain from sustainability investments, an effective communication program should be made with key stakeholders because stakeholders' perception toward such practices is a key driver of business benefits and competitive advantages.

\subsection{Limitations}

This research has some limitations that need to be considered. First, the data were collected from a small sample of firms in Thailand. Thus, the results cannot not be generalized to the population of firms in the country. For this reason, future research will need to expand the data coverage to strengthen the generalizability of the results. Second, this research inferred the findings from the analysis of cross-sectional data. Thus, the causality between the constructs may not be verified. Thirdly, the use of a self-reported survey and subjective measures may cause some bias in the measurements.

\section{References}

Andreassen, T. W., \& Lindestad, B. (1998). Customer loyalty and complex services. International Journal of service Industry management. https://doi.org/10.1108/09564239810199923

Balachandran, V., \& Chandrasekaran, V. (2011). Corporate Governance, Ethics and Social Responsibility (2nd 
ed.). New Delhi, India: PHI Learning Pvt. Ltd.

Baldassarre, B., Calabretta, G., Bocken, N., \& Jaskiewicz, T. (2017). Bridging sustainable business model innovation and user-driven innovation: A process for sustainable value proposition design. Journal of Cleaner Production, 147, 175-186. https://doi.org/10.1016/j.jclepro.2017.01.081

Brammer, S., Millington, A., \& Rayton, B. (2007). The contribution of corporate social responsibility to organizational commitment. The International Journal of Human Resource Management, 18(10), 1701-1719. https://doi.org/10.1080/09585190701570866

Brammer, S. J., \& Pavelin, S. (2006). Corporate reputation and social performance: The importance of fit. Journal of management studies, 43(3), 435-455. https://doi.org/10.1111/j.1467-6486.2006.00597.x

Brown, B. C. (2011). Conscious leadership for sustainability: How leaders with a late-stage action logic design and engage in sustainability initiatives [dissertation]. Fielding Graduate University. Retrieved from http://citeseerx.ist.psu.edu/viewdoc/download?doi=10.1.1.465.6432\&rep=rep1\&type=pdf

Charoensukmongkol, P. (2015). Cultural intelligence of entrepreneurs and international network ties: The case of small and medium manufacturing firms in Thailand. Management Research Review, 38(4), 421-436. https://doi.org/10.1108/MRR-09-2013-0214

Charoensukmongkol, P. (2016). The interconnections between bribery, political network, government supports, and their consequences on export performance of small and medium enterprises in Thailand. Journal of International Entrepreneurship, 14(2), 259-276. https://doi.org/10.1007/s10843-016-0164-1

Charoensukmongkol, P. (2020). The interplay between firm resources and government agency social capital on Thai firms' satisfaction with export performance. International Journal of Globalisation and Small Business, 11(1), 18-38. https://doi.org/10.1504/IJGSB.2020.105581

Charoensukmongkol, P., \& Sasatanun, P. (2017). Social media use for CRM and business performance satisfaction: The moderating roles of social skills and social media sales intensity. Asia Pacific Management Review, 22(1), 25-34. https://doi.org/10.1016/j.apmrv.2016.10.005

Chauvin, K. W., \& Hirschey, M. (1994). Goodwill, profitability, and the market value of the firm. Journal of Accounting and Public Policy, 13(2), 159-180. https://doi.org/10.1016/0278-4254(94)90018-3

Choi, S., \& Ng, A. (2011). Environmental and economic dimensions of sustainability and price effects on consumer responses. Journal of Business Ethics, 104(2), 269-282. https://doi.org/10.1007/s10551-011-0908-8

Cronin, J. J., Smith, J. S., Gleim, M. R., Ramirez, E., \& Martinez, J. D. (2011). Green marketing strategies: An examination of stakeholders and the opportunities they present. Journal of the Academy of Marketing Science, 39(1), 158-174. https://doi.org/10.1007/s11747-010-0227-0

Dahlsrud, A. (2008). How corporate social responsibility is defined: An analysis of 37 definitions. Corporate Social Responsibility and Environmental Management, 15(1), 1-13. https://doi.org/10.1002/csr.132

Dowling, G. (2001). Creating Corporate Reputations. Oxford, UK: Oxford University Press.

Efron, B., Rogosa, D., \& Tibshirani, R. (2004). Resampling methods of estimation. In N. J. Smelser \& P. B. Baltes (Eds.), International Encyclopedia of the Social \& Behavioral Sciences (pp. 13216-13220). New York, NY: Elsevier.

Elkington, J. (1999). Cannibals with forks. The triple bottom line of the 21 st century. Capstone. In: Oxford.

Fombrun, C. J. (1996). Reputation: Realizing value from the corporate image. Boston, Mass: Harvard Business School Press.

Fombrun, C. J. (2001). Corporate reputations as economic assets. The Blackwell Handbook of Strategic Management, Blackwell Publishers, Malden, 33(2), 233-258.

Fombrun, C. J., Gardberg, N. A., \& Sever, J. M. (2000). The Reputation Quotient SM: A multi-stakeholder measure of corporate reputation. Journal of brand management, 7(4), 241-255. https://doi.org/10.1057/bm.2000.10

Fornell, C., \& Larcker, D. F. (1981). Evaluating structural equation models with unobservable variables and measurement error. Journal of Marketing Research, 18(1), 39-50. https://doi.org/10.1177/002224378101800104

Goodland, R. (1995). The concept of environmental sustainability. Annual review of ecology and systematics, 
26(1), 1-24. https://doi.org/10.1146/annurev.es.26.110195.000245

Govindarajan, V., \& Srinivas, S. (2012). Shareholder capitalism to responsible capitalism. The Times of India. Retrieved from http://timesofindia.indiatimes.com/articleshow/17790281.cms?utm_source=contentofinter est\&utm_medium=text\&utm_campaign=cppst

Gray, R., Kouhy, R., \& Lavers, S. (1995). Corporate social and environmental reporting: A review and a longitudinal study of UK disclosure. Accounting, Auditing \& Accountability Journal, 8(2), 47-77. https://doi.org/10.1108/09513579510146996

Guang, X., \& Charoensukmongkol, P. (2020). The effects of cultural intelligence on leadership performance among Chinese expatriates working in Thailand. Asian Business \& Management. https://doi.org/10.1057/s41291-020-00112-4

Gupta, S., \& Kumar, V. (2013). Sustainability as corporate culture of a brand for superior performance. Journal of World Business, 48(3), 311-320. https://doi.org/10.1016/j.jwb.2012.07.015

Hair, J. F., Ringle, C. M., \& Sarstedt, M. (2011). PLS-sem: Indeed a silver bullet. The Journal of Marketing Theory and Practice, 19(2), 139-152. https://doi.org/10.2753/MTP1069-6679190202

Hair Jr, J. F., Hult, G. T. M., Ringle, C., \& Sarstedt, M. (2016). A primer on partial least squares structural equation modeling (PLS-SEM): Sage Publications.

Koirala, M., \& Charoensukmongkol, P. (2020). Contributions of CSR Perception to Employees Commitment and Job Satisfaction: Does Personal Income Matter? Kasetsart Journal of Social Sciences, 41(2), 1-5. https://doi.org/10.34044/j.kjss.2020.41.2.06

Kotha, S., Rajgopal, S., \& Rindova, V. (2001). Reputation building and performance: An empirical analysis of the top-50 pure internet firms. European Management Journal, 19(6), 571-586. https://doi.org/10.1016/S0263-2373(01)00083-4

Kumar, V., \& Christodoulopoulou, A. (2014). Sustainability and branding: An integrated perspective. Industrial Marketing Management, 43(1), 6-15. https://doi.org/10.1016/j.indmarman.2013.06.008

Lee, J., \& Roh, J. J. (2012). Revisiting corporate reputation and firm performance link. Benchmarking: An International Journal, 19(4/5), 649-664. https://doi.org/10.1108/14635771211258061

Luo, X., \& Bhattacharya, C. B. (2006). Corporate social responsibility, customer satisfaction, and market value. Journal of marketing, 70(4), 1-18. https://doi.org/10.1509/jmkg.70.4.001

Marrewijk, M. V., \& Werre, M. (2003). Multiple Levels of Corporate Sustainability. Journal of Business Ethics, 44, 107-119. https://doi.org/10.1023/A:1023383229086

Martínez, P., \& del Bosque, I. R. (2014). Sustainability dimensions: A source to enhance corporate reputation. Corporate Reputation Review, 17(4), 239-253. https://doi.org/10.1057/crr.2014.13

Miles, M. P., \& Covin, J. G. (2000). Environmental marketing: A source of reputational, competitive, and financial advantage. Journal of Business Ethics, 23(3), 299-311. https://doi.org/10.1023/A:1006214509281

Nguyen, N., \& Leblanc, G. (2001). Corporate image and corporate reputation in customers' retention decisions in services. Journal of retailing and Consumer Services, 8(4), 227-236. https://doi.org/10.1016/S0969-6989(00)00029-1

Nunnally, J. C. (1978). Psychometric Theory (2nd ed.). New York, NY: McGraw-Hill.

Orlitzky, M., Siegel, D. S., \& Waldman, D. A. (2011). Strategic corporate social responsibility and environmental sustainability. Business \& Society, 50(1), 6-27. https://doi.org/10.1177/0007650310394323

Park, J., Lee, H., \& Kim, C. (2014). Corporate social responsibilities, consumer trust and corporate reputation: South Korean consumers' perspectives. Journal of Business Research, 67(3), 295-302. https://doi.org/10.1016/j.jbusres.2013.05.016

Petter, S., Straub, D., \& Rai, A. (2007). Specifying Formative Constructs in Information Systems Research. MIS quarterly, 31(4), 623-656. https://doi.org/10.2307/25148814

Pfau, M., Haigh, M. M., Sims, J., \& Wigley, S. (2008). The influence of corporate social responsibility campaigns on public opinion. Corporate Reputation Review, 11(2), 145-154. https://doi.org/10.1057/crr.2008.14

Phungsoonthorn, T., \& Charoensukmongkol, P. (2019). Antecedents and outcomes associated with a sense of 
place toward the organization of Myanmar migrant workers in Thailand. Equality, Diversity and Inclusion, 39(2), 195-218. https://doi.org/10.1108/EDI-06-2019-0177

Preacher, K. J., \& Hayes, A. F. (2004). SPSS and SAS procedures for estimating indirect effects in simple mediation models. Behavior research methods, instruments, \& computers, 36(4), 717-731. https://doi.org/10.3758/BF03206553

Roberts, P. W., \& Dowling, G. R. (2002). Corporate reputation and sustained superior financial performance. Strategic Management Journal, 23(12), 1077-1093. https://doi.org/10.1002/smj.274

Sapienza, H. J., Smith, K. G., \& Gannon, M. J. (1988). Using subjective evaluations of organizational performance in small business research. American Journal of Small Business, 12(3), 45-54. https://doi.org/10.1177/104225878801200304

Shapiro, C. (1982). Consumer information, product quality, and seller reputation. The Bell Journal of Economics, 20-35. https://doi.org/10.2307/3003427

Sheth, J. N., Sethia, N. K., \& Srinivas, S. (2011). Mindful consumption: A customer-centric approach to sustainability. Journal of the Academy of Marketing Science, 39(1), 21-39. https://doi.org/10.1007/s11747-010-0216-3

Slaper, T. F., \& Hall, T. J. (2011). The triple bottom line: What is it and how does it work. Indiana business review, 86(1), 4-8.

Sroufe, R., \& Gopalakrishna-Remani, V. (2019). Management, social sustainability, reputation, and financial performance relationships: An empirical examination of US firms. Organization \& Environment, 32(3), 331-362. https://doi.org/10.1177/1086026618756611

Tarsakoo, P., \& Charoensukmongkol, P. (2019). Dimensions of social media marketing capabilities and their contribution to business performance of firms in Thailand. Journal of Asia Business Studies, 14(4), 441-461. https://doi.org/10.1108/jabs-07-2018-0204

Unerman, J., \& Bennett, M. (2004). Increased stakeholder dialogue and the internet: Towards greater corporate accountability or reinforcing capitalist hegemony? Accounting, Organizations and Society, 29(7), 685-707. https://doi.org/10.1016/j.aos.2003.10.009

Vaitoonkiat, E., \& Charoensukmongkol, P. (2020a). Interaction effect of entrepreneurial orientation and stakeholder orientation on the business performance of firms in the steel fabrication industry in Thailand. Journal of Entrepreneurship in Emerging Economies, 12(4), 453-473. https://doi.org/10.1108/JEEE-05-2019-0072

Vaitoonkiat, E., \& Charoensukmongkol, P. (2020b). Stakeholder orientation's contribution to firm performance: The moderating effect of perceived market uncertainty. Management Research Review, 43(7), 863-883. https://doi.org/10.1108/mrr-07-2019-0296

Vij, S., \& Bedi, H. S. (2016). Are subjective business performance measures justified? International Journal of Productivity and Performance Management, 65(5), 603-621. https://doi.org/10.1108/IJPPM-12-2014-0196

Yau, O. H., Chow, R. P., Sin, L. Y., Alan, C., Luk, C.-L., \& Lee, J. S. (2007). Developing a scale for stakeholder orientation. European Journal of marketing, $1306-1327$. https://doi.org/10.1108/03090560710821198

\section{Copyrights}

Copyright for this article is retained by the author(s), with first publication rights granted to the journal.

This is an open-access article distributed under the terms and conditions of the Creative Commons Attribution license (http://creativecommons.org/licenses/by/4.0/). 